\title{
The Future of Pension Plans in the EU Internal Market - Coping with Trade-Offs Between Social Rights and Capital Markets
}

NAZARÉ DA COSTA CABRAL and NUNO CUNHA RODRIGUES (Eds.) Springer, Cham, 2019, pp. 349

Book review by PREDRAG BEJAKOVIĆ* https://doi.org/10.3326/pse.44.4.7

${ }^{*}$ Received: January 27, 2020

Accepted: February 11, 2020

Predrag BEJAKOVIĆ, Ph.D.

Institute of Public Finance, Smičiklasova 21, 10000 Zagreb, Croatia e-mail: predrag.bejakovic@ijf.hr ORCiD: 0000-0002-4164-8220 
Pension systems around the world are in more or less serious problems. The reasons are manifold, and are primarily caused by demographic changes (increased longevity and decreased natural growth) but are also systemic (the high outlays on pension expenditures that have a relatively small - or at least an insufficient impact on the well-being of the older population). The new publication The Future of Pension Plans in the EU Internal Market - Coping with Trade-Offs Between Social Rights and Capital Markets ${ }^{1}$ published by Springer provides new light on the situation and possible solutions for the phenomenon.

In the introduction the editors briefly explain the goal of the publication and the contributions by particular authors. In the circumstances of the period after the serious financial and economic crisis, pension systems are at a crossroad between the development of the inner capital market and the outlook of a new role of the EU regarding social policy. Such a policy should be an efficient response to common challenges, like the digital revolution, ageing, globalisation, new forms of work and the future of employment.

The first section begins with the contribution of Miguel Coelho dedicated to a characterization and the comparability of old-age pension systems. The author divides the mentioned pension models according to three principles: (a) capitalised versus unfunded systems, (b) actuarial versus non-actuarial systems, and (c) defined benefit (DB) versus defined contribution (DC) systems. The author concludes that a capitalised system, with defined contributions and actuarial fairness, has advantages over a PAYGO system because it enables improved protection against demographic changes, has limited financial liabilities, enables the development and strengthening of capital markets and better prevents politicization of the pension system.

Boulhol and Lüske in their contribution analyse what is new in the discussion about a PAYGO system (where there is a transfer from current employees to current pensioners) as against funded pensions (current workers save a part of their contributions which are invested in the financial market and then used to pay pensions when people retire). The authors explain that the relative benefits and costs of a shift from the previous to the second mostly depend on whether the observed economy is sufficiently dynamically efficient. Boulhol and Lüske point out that this shift creates winners and losers and therefore necessarily entails some new arrangement of redistribution.

Yves Stevens examines the role of the government in creating, or improving access, to funded or unfunded pension systems. He assesses the models of capitalised or PAYGO systems not only from the standpoint of risk sharing, but also from the historical and ideological basis of different notions of pension models and their causal meaning and significance. It is the role of a government to decide on the spread of these risks. The term pension has multiple meanings with different connotations, leading to what the author titles a national pension identity. 
In a number of OECD countries, in addition to PAYGO models, over time occupational pensions have been developed. These models often started out in particular sectors before becoming widely accepted and affect a significant part of the labour force. Maria Teresa Garcia identifies the main causes of the move from DB to DC plans. The shift is present in most of the developed countries, and therefore risks related to retirement and financial affairs are transferred to individuals.

Most OECD countries during the last 20 years have recorded adverse demographic trends primarily due to ageing populations. Falilou Fall pays attention to important issues of the sustainability and adequacy of different pension systems across OECD members. With the goal of improving sustainability, many countries have reformed their pension systems by a combination of different policy measures.

The second section of the book begins with the contribution by Belke and Allroggen dedicated to the analysis of the capital markets union (CMU) and its role in saving for retirement. The CMU has two main aims: improving investment opportunities across Europe and enhancing financing options for business. The CMU aims for a more stable and resilient financial sector through deeper integration, creating a single market for capital by eliminating barriers to cross-border investments and improving access to financing for all business around the EU.

Gabriel Bernardino examines the measures for solving the problem of the increasing financial gap between what people expect to obtain as their retirement income and what they actually will receive. The author addresses the role of improved regulation and the importance of supervisory authorities, particularly the European Insurance and Occupational Pensions Authority, in regaining trust in pension plans and products in the conditions after the economic crisis. Recent corporate failures have clearly shown the risk that pension fund members might lose a considerable part of their retirement income and have confirmed that the potential effects of the current insufficient financial resources are not to be neglected.

Davoine and Forstner examine the long-term effects on the pension system of separate and integrated capital markets. The latter case, obtained through a capital market union, is more beneficial if other countries in the market union have PAYGO systems. Households in a country that has introduced a capitalised pension system would enjoy long-term welfare gains in a scope between $0.3 \%$ and $0.5 \%$ of lifetime consumption if the country is in a capital market union, compared to separated capital markets. The main reason is that a capital-funded pension system results in a growth of national savings, since contributions that are collected are saved for future consumption, instead of being immediately consumed by pensioners in a country with a PAYGO system.

As a measure for improvement of the unfavourable financial situation in Portugal, Merton, Muralidhar and Pinto Ferreira propose the introduction of a new innovative type of sovereign contingent debt instrument. This consists of standard-of-living 
indexed, forward starting income-only securities - SeLFIES. Such an instrument can simplify retirement planning, ensure retirement security, and also improve the government's possibilities for debt financing and funding the construction of infrastructure.

Nuno Cunha Rodrigues examines the role of the PEPP and the CMU as measures to address the fact that pension rights are not portable across EU borders. The most important aim of the PEPP is to boost the cross-border mobility by providing a possibility for people who have worked or intend to work in various EU Member States. Several measures have already been taken towards stronger coordination of national economic and monetary policies intended to mitigate the impact of factors that hinder mobility.

Karel Lannoo is quite sceptical of the final success of the PEPP. The reason is that the unclear, unattractive and unsuitable text agreed between the European Parliament (EP) and the EU Council is not likely to be useful in practice. Due to heavy pressure from various sides, the text was fragmented, watered down or replaced so the final version of the PEPP was disappointing. The text in the final form has become applicable only to individual pension voluntary savings in the third pillar.

Publicized in February 2019, as an instrument to enhance the portability of pension rights, the PEPP did not solve problems related with the deepening financialization within the EU and the linked negative consequences for pension regimes. Caldas explains the key aspects of financialized and stresses that due to various factors (primarily because of complex, non-transparent and not standardized decision making processes), measures for establishing a Capital Markets Union did not achieve the desired results. Therefore, the EU is still actively searching an optimal model for reviving the role of financial markets in the EU, the development of the CMU and implementation of the PEPP as its important instrument.

The last section of the book is dedicated to a new opportunity for the EU Social Policy. Nazaré da Costa Cabral writes about an optimal development of pension systems that should choose between paying more respect to social rights or being more oriented towards financial markets. The author offers two hypothetical alternatives for the future proposal of pension schemes: the personal insurance model and the universal tax-financed model.

The notion European social model is quite often used in public discussion, but with numerous political connotations. It is a theme of interest for Pedro Adão e Silva and Patrícia Cadeiras. The authors offer an interesting historical overview of social policy in the EU, since the original Treaties until the present circumstances. After more than 60 years of integration, the core of the social policies continues to be under the control of nation states. The soft nature of such a policy may be a 
most important asset to ensure the required flexibility in response to the various challenges from demographic changes to the new forms of work.

Spasova, Louvaris Fasois and Vanhercke discuss the main trends of pension reforms in EU member states in the period 2014-2019, looking at how the issue of pension adequacy has been solved. Fully aware that adequacy and sustainability in pension systems are closely intertwined, they analyse reforms related to prolonging working lives; measures for the protection of pension adequacy; and actions for preserving income during retirement. Although pension insurance mostly remains a national competence, one should not neglect the influence and significance of various proposals by the World Bank and the IMF. In approximately the last 20 years, the EU also became an important factor contributing to pensions' policy mostly through the Open Method of Coordination and the European Semester.

Wöss and Türk challenge conservative opinion on the sustainability of the pension systems, deeming that the best solution for pension adequacy and sustainability is an increase in employment rates. As a positive example for measuring the dependency ratio, the author presents the 'dependency ratio calculator' developed by the Austrian Chamber of Labour. The instrument applies graphics of the age structure and economic status of population to calculate demographic and economic dependency ratios. Successful integration into the labour market of all working age persons would significantly improve the future economic dependency ratios and, therefore improve pension adequacy and financial sustainability.

Ivana Vukorepa, from the Faculty of Law, University of Zagreb, together with Joren and Strban, explains how ageing societies and society fluidity can impact pension schemes and coordination rules at the EU level, for both the $1^{\text {st }}$ and the $2^{\text {nd }}$ second pillars of pension insurance. Fluidity in this context means new patterns of (organising) work and mobility, or in other words non-standard or unstable forms of employment (like fixed-term contracts, telework, part-time work, traineeships and student work, temporary agency work), which are often not included in pension insurance.

It is a demanding task to sum up all the praiseworthy messages from this really excellent book. Briefly, as mentioned earlier, there are no optimal pension models and the reform process should take into account the context in which the reforms are being implemented. Depending on the setting, the adoption of a particular approach and given model may have different outcomes. The goal of the adopted measures and the numerous reforms was to lower public expenditure. To address such complex and demanding tasks, a number of policy ideas have been developed and various proposals prepared, but, without doubt, further systematic efforts will be needed. 


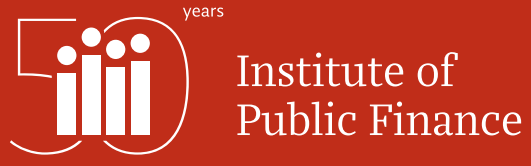

